\title{
THE VEGETATION AND LIFE ZONES OF GEORGE RIVER, EASTERN UNGAVA AND THE WELFARE OF THE NATIVES \\ (A PRELIMINARY NOTE)
}

By Jacques Rousseau

Tor more than 300 miles, the George River, between the Province of 4 Quebec and Labrador, flows from the height of land, north of Lake Michikamau, to Ungava Bay. Ranging from half a mile to a mile in width and at times enlarging into lakes three to five miles wide, its water supply is very high.

We would logically conclude that so big a river would at least be well-known to Indian hunters. However they seldom, if ever, travel it from source to mouth or vice versa because of the incline of the river. There are only a couple of falls and, the lakes excepted, it is a succession of lengthy rapids, sometimes five miles long and all linked by swift waters. From Indian House Lake to the sea, over a distance of approximately one hundred miles, the river drops about one thousand feet and might well be considered as a more or less continuous series of rapids. For this reason, the Barren Ground band, which once inhabited the region of Indian House, knew but a section of the river, travelling mainly laterally to Fort Chimo or the Labrador coast. The first person to cover the river completely was, apparently Mrs. Leonidas Hubbard in 1905. Later came Dillon Wallace. Mrs. Hubbard has given us a good map and an interesting account ${ }^{1}$ in which may be found a very good description of the territory. After this trip, forty-two years elapsed before others travelled down the river from its very source. The trip made by our party in the 1947 summer was the first biological (and also geological) survey of the river.

\section{Arctic and Subarctic Zone}

The plateau, at the height of land, is covered by the taiga or subarctic forest, consisting mainly of black spruce, tamarack and occasionally white spruce and balsam fir, with a carpet of Cladonia alpestris and C. rangiferina and several ericaceous plants. But, beyond $55^{\circ}$ lat. N., trees become restricted to river valleys and occupy often less than five per cent of the whole territory.

The limit of the arctic zone, considered from the plant life point of view, is generally placed between the 58 th and 6oth parallels in Quebec, because old explorers such as Low (who had not travelled the George river but the Kaniapiskau and Koksoak), mentioned or brought back some fragments of trees. The herbarium specimens in existence and such brief descriptions are responsible for the present interpretation. It is unwise to accept the absolute limit of trees as the limit of the Arctic vegetation zone. One drawback in doing so is that such an assumption is not in accordance with actual fact. 
Between $55^{\circ}$ lat. N., and approximately the parallel of $59^{\circ}$, except for some small thickets at the bottom of valleys or occasionally on favourably exposed slopes, the territory belongs more appropriately to the arctic barrens, the dry tundra consisting of Arctous Alpina, Empetrum nigrum, Ledum palustre, Salix herbacea, Salix uva-ursi, Diapensia lapponica, Cledonia alpestris and other lichens, etc. It is also worthwhile noticing that arctic conditions are more typical inland between $56^{\circ} \mathrm{N}$., and $57^{\circ} \mathrm{N}$., than between $57^{\circ} 30^{\prime}$ and $58^{\circ}$. As, north of the $57^{\circ}$ the river descends a slope of about one thousand feet within less than one hundred miles, the decrease in altitude apparently compensates for the increase in latitude; the climate is milder and consequently the forest thickets are denser, although never the continuous subarctic forest.

North of the $55^{\circ}$ lat. N., on either side of the George river, the continuous subarctic forest zone (only bare of trees in peat-bogs, lakes and occasionally on rather abrupt rocky exposures) is succeeded within approximately $\mathrm{Io}^{\prime}$ of latitude (approximately $\mathrm{I} 2$ miles), with practically no transition, by the aforesaid arctic formation. This zone, situated between $55^{\circ}$ and $59^{\circ}$ offers more or less a parallel case with that of the mixed forest lying between the deciduous woods and the coniferous forest.

The succession of plant life zones in the north (at least in the George river district) should be summarized as follows: I) The subarctic forest extending north to the $55^{\text {th }}$ parallel. 2) The first section of the arctic zone with small "islands" of subarctic forests (rarely more than 5 p.c. to ro p.c. of the area), between $55^{\circ} \mathrm{N}$. and approximately $59^{\circ} \mathrm{N}$. 3) The second section of the arctic zone, north of the absolute limit of trees (north of $59^{\circ} \mathrm{N}$.) with no trace of "islands" of subarctic forests. I am under the impression that this new zonation of plant life coincides closely with climate zones.

\section{Flora in relation to glaciation}

Another observation noted on the 1947 botanical survey of the George river, and which will probably influence our knowledge of northeastern biogeography, is the occurrence on the inland plateau, of a great number of species found in the Gaspé region which had heretofore been considered by some botanists as indicators of nunataks. As the Arctic Archipelago is also supposed to have been unglaciated during the recent glacial period, there has been no real botanical evidence opposing the Gaspé nunatak theory. There is such a thing as a nunatak and a preglacial relic, but the question which arises is, "Was the Gaspé peninsula unglaciated?" Evidence in favour of Gaspé non-glaciation may appear feeble, but no attempt to date to overthrow the hypothesis or even to weaken it purely on a basis of biogeographical studies has succeeded.

That the George river district was glaciated there need be no doubt if such a phenomenon as a continental glacier ever existed, not only because 
the district is near the centre of the Labradorian glacier, as based on Low's preliminary reconnaissance, but on evidence of the occurrence of moraines themselves. The whole territory is a gigantic moraine, more or less, and even the highest summits (about I 800 feet high) are covered with huge granitic boulders of sub-recent origin. If they were polished in transportation they are not weathered as they would be had they been deposited during some previous and more ancient glaciation. Consequently, none of the plants found in the George river district can be used as indicators of an unglaciated area. The list of plants of supposedly unglaciated areas will thus be reduced so that the hypothesis of a Gaspé nunatak will need evidence from outside the botanical field to remain a living hypothesis ${ }^{2}$. We do not presume that the associations of the George river district are proof that the Gaspé district has not been glaciated, but discovery on the George of many of the elements of this Gaspésian flora eliminates many of them considered heretofore as a proof of non-glaciation.

\section{Man and animal life}

The George river was, at one time, the realm of the caribou. Herds containing thousands of head met there at the season's end after having grazed unmolested on the lichen-covered hills, during the summer months. Herds are now reduced to only a few heads. Intensive hunting, if illness is not considered, is responsible for the decrease. Food is not a factor because the vegetation of the plateau and the hills would be sufficient for grazing thousands of animals. Unfortunately, in the old days (and until but a few years ago) the inland Naskapi and the Labrador hunters, white, Naskapi or Eskimo, each year wiped out entire herds. When they found the caribou, the natives slaughtered them mercilessly, keeping for themselves sometimes only the marrow, some of the skins and the tongues which they sold later on reaching the coast.

A group of Naskapi, the Barren Ground band, formerly occupied the long Indian House lake, a widening in the George river. When Mrs. Hubbard passed through the territory in 1905, there were about thirty families camping at the southern end of the lake. When Cabot arrived there from the Labrador coast in 1910, they had moved a few miles northward. During my trip during the 1947 summer, ethnological studies (I would prefer to say archaeological studies) permitted me to follow the migration of the band towards the north for about one hundred miles. During the migration, spaced over approximately forty years, the Indians had gradually and consistently modified their living conditions, abandoning the skin tent for the canvas and the primitive fire place for the light camp stove. In the meantime, they became fewer. The tent sites, about thirty at the spot where Mrs. Hubbard met them in 1905, dwindled to only five or six when the natives established themselves less than a decade ago at the northern end of their run. No Indians now inhabit the territory 
and the last hunters withdrew three years ago. The remnants of the Barren Ground people, no doubt joined the Fort MacKenzie Indians or the other bands inhabiting the Labrador coast.

From a human point of view, the George river basin, covering 30,0oo square miles, is a desert which Indians prefer avoiding because of the scarcity of food. It is a common saying among them that to winter over in the basin without being fully supplied means death.

I am nevertheless convinced that the territory could eventually be made into an important "reservoir" of game for an extensive native population. Caribou would increase at a rapid rate if fully protected on account of the ample plant food supply. Nevertheless, if the protection were to consist only of the restriction of hunting over a specified period, the results would be rather poor. How can we prevent the natives hunting the caribou when it is one of their basic requirements? Even if the George river district were closed to hunters, (which is in fact the present situation), no good would result, as the caribou, a migratory animal, would not be adequately protected along the inhabited Labrador coast. The slaughtering of caribou on the coast contributed more to the fantastic decrease in number than the inland hunting of the few dozen Indian families.

\section{Introduction of Reindeer and Mountain Goats}

Better than direct relief, which would soon lead the native to rely solely on government help, would be the introduction of another animal as a substitute. Two solutions, one as good as the other, may be considered; the reindeer and the rocky mountain goat. The George river territory can accommodate large reindeer herds sufficient for a large population, provided skilled herdsmen are hired to train the local inhabitants. The introduction of mountain goats will be simpler for as soon as they are introduced into the territory, they will immediately choose those parts of the territory which are of little use to the caribou or the reindeer. One animal consequently will not compete with the other. The northern part of the George river district is very hilly and is particularly suited to goats.

I do not hesitate to recommend to the Canadian federal authorities the introduction of reindeer herds under the supervision of trained native herders. As for the introduction of mountain goats and the proper protection of the caribou, only a joint program under which both Quebec and Newfoundland share the expense proportionally to the number of inhabitants of the territory, will succeed in establishing the game in an immense territory and save the native population from starvation or expensive direct relief.

${ }^{1}$ Hubbard, Mrs. Leonidas. A woman's way through unknown Labrador. An account of the exploration of the Nascaupee and George rivers. Toronto, (William Briggs) $338 \mathrm{pp}$. one map, numerous illustrations, 1908.

${ }^{2}$ I can only touch these problems summarily here. They will be discussed at greater length in a forthcoming technical paper. 